\title{
Drip fertigation quality monitoring using monopotassium phosphate on different slopes
}

\author{
Allan Remor Lopes ${ }^{1 *} \oplus$, Marcio Antonio Vilas Boas $^{1} \oplus$, Benedito Martins Gomes ${ }^{1} \oplus$, \\ Rosebel Trindade Cunha Prates ${ }^{1} \odot$, Felix Augusto Pazuch ${ }^{1} \odot$, Luciano Dalla Corte ${ }^{1} \odot$

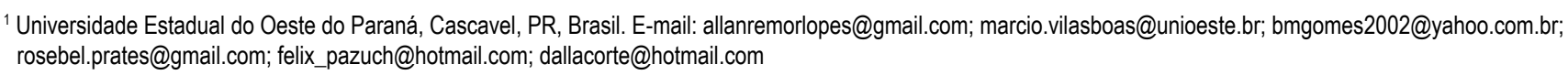

ABSTRACT: The use of monopotassium phosphate is an option for phosphate fertigation. Determining the application uniformity of a fertigation system is necessary for an adequate evaluation. The present work was conducted to monitor the quality of a drip irrigation system with monopotassium phosphate on different slopes. The experiment was conducted under laboratory conditions, on a test bench, and 25 tests were performed for each inclination (level, upslope, and downslope). The uniformity was determined using the Christiansen's uniformity coefficient (CUC) and monitored by the Shewhart and exponentially weighted moving average (EWMA) control charts. The uniformity of the system was excellent for all slopes, and the uniformities in the level and downslope topographies were superior to that in upslope. The EWMA control chart was more sensitive, being out of statistical control for upslope and downslope, topographies, and displayed trends which are not shown in the Shewhart control chart.

Key words: control charts; exponentially weighted moving average; microirrigation; Shewhart control chart; uniformity

\section{Monitoramento da qualidade da fertirrigação por gotejamento utilizando fosfato monopotássico em diferentes inclinações}

RESUMO: A utilização do fosfato monopotássico é uma opção para a fertirrigação fosfatada. Para uma avaliação adequada de um sistema de fertirrigação é necessário a determinação da sua uniformidade de aplicação. $O$ trabalho foi realizado com o objetivo de monitorar a qualidade de um sistema de fertirrigação por gotejamento com fosfato monopotássico em diferentes inclinações. 0 experimento foi conduzido em condições laboratoriais em uma bancada de testes, onde foram realizados 25 ensaios para cada inclinação (Nível, Aclive e Declive). Para cada ensaio foi determinado o coeficiente de uniformidade de Christiansen (CUC) e monitorada pelos gráficos de controle de Shewhart e da Média Móvel Exponencialmente Ponderada (MMEP). Em todas inclinações a uniformidade foi excelente, sendo que as uniformidades do sistema em nível e declive foram superiores a inclinação em aclive. 0 gráfico de Shewhart se mostrou sob controle estatístico para as inclinações em nível e declive, e fora para aclive. O gráfico MMEP se mostrou mais sensível estando fora de controle estatístico para aclive e declive, além de mostrar tendências não apresentadas no gráfico Shewhart.

Palavras-chave: gráficos de controle; média móvel exponencialmente ponderada; microirrigação; gráfico de controle Shewhart; uniformidade 


\section{Introduction}

Drip irrigation is the most widespread irrigation system, and has the following characteristics compared with other irrigation systems: higher installation cost, greater efficiency, lower energy consumption, favorable phytosanitary control, and viable and favorable fertigation (Cunha et al., 2017).

Fertigation consists in applying soluble fertilizers through irrigation systems. It is a common practice in modern irrigated agriculture and can be used with fertilizers of different forms (solid or liquid) and types, including phosphates.

Phosphorus ( $P$ ) is an essential nutrient and plays an important role in various crop activities. It is responsible for several important structural functions for plant development, and participates in photosynthesis, respiration, cell growth, and mainly energy supply, thus, the element directly influences the initial development of plants (Vieira et al., 2015).

Despite the innumerable benefits of using phosphorous in plant development, the use of phosphate fertilizers in drip fertigation has some obstacles on the part of rural producers, such as the low solubility of most phosphates, and the ease of nutrient precipitation, which causes the emitters to clog (Coelho et al., 2011).

However, drip fertigation increases the phosphorus distribution in the soil, as it causes greater concentration in a narrow band, saturating the attachment sites close to the application point. However, applying it on the surface with sprinkler irrigation is $n$ due to the low mobility of phosphorous in the soil (Zanini et al., 2007). Foratto et al. (2007) proposed that in most fertilizers in phosphate fertigation can cause obstruction of emitters and incrustation in the pipes, the solution to these problems may be phosphates with effective solubility, such as monopotassium phosphate (MKP).

Monopotassium phosphate is used in scenarios where $P$ is needed and nitrogen $(\mathrm{N})$ is not. In addition, it has the added benefit of providing a high potassium $(\mathrm{K})$ concentration and high solubility. It also promotes an increase in fruit production and quality (Fan et al., 2011; Sajyan et al., 2018), chlorophyll content and dry matter accumulation (Chapagain \& Wiesman, 2004). Despite that MKP is known to have numerous advantages and its uses have already been consolidated, its use with a drip irrigation system is yet to be evaluated.

An evaluation index called Christiansen's uniformity coefficient (CUC) is used to assess the ideal functioning of a fertigation system, which directly influences management, quality, efficiency, and cost, as well as the crop performance in the field. CUC is an important performance indicator of the fertigation system (Cunha et al., 2018).

Several factors influence the uniformity of a fertigation system: the flow, pressure, form, system components and solubility of the fertilizer, operating time and topography. Lopes et al. (2019) observed that the water distribution in sloping areas in irrigation is very different from that in flat areas. ASABE (1996) recommends the use in upslope (2\%), level $(0 \%)$ and downslope (2\%) to perform bench evaluation of drip irrigation tests on different slopes.
Statistical quality control is a powerful tool for detecting problems, as it demonstrates stability and variability. It quickly detects changes in a process, enabling an investigation and corrective action implementation before many nonconformities start to occur (Conceição et al., 2018). Chincilla et al. (2018) concluded that statistical quality control can be a valuable tool in monitoring irrigation systems. This technique generates easy to interpret graphs which that show if the uniformity process of an irrigation system is efficient or if large variations exist in its functioning (Orsatto et al., 2015).

Among the various existing control charts, the Shewhart and exponentially weighted moving average (EWMA) charts were used in this research. The Shewhart control chart is a method of presenting and comparing information. It stands out among the other tools due to its operational simplicity and effectiveness in detecting problems. The EWMA control charts are recommended due to their accuracy, as they can identify small deviations in a process (Siqueira et al., 2018).

In view of the above, the objective of this research is to evaluate MKP fertigation in a drip system under different topographic situations, determining and monitoring the flow uniformity.

\section{Materials and Methods}

The experiment was carried out from June 10 to 17 in 2019. The tests were performed in laboratory conditions on a $5 \mathrm{~m}$ long bench with four lateral lines. The lateral line return was performed using pulleys, and lateral lines with $10 \mathrm{~m}$ were obtained (Figure 1). The bench consisted of an Acquapump motor pump (Ferrari) with a $0.5 \mathrm{hp}$ engine, maximum flow (Q) of $1.8 \mathrm{~m}^{3} \mathrm{~h}^{-1}$, and maximum head of 22.0 water column gauge, a control head with 120 mesh disk filter, and a BERMAD model 0075 PRVy pressure controller.

The drip tubes tested were IRRITEC model P1 products, spaced at $0.5 \mathrm{~m}$, featuring $16.00 \mathrm{~mm}$ diameter, maximum working pressure of $80 \mathrm{kPa}$, proportionality coefficient of the emitter equation (K) of 1.26, and discharge exponent (x) of 0.48 .

Yara Krista MKP fertilizer was used in the tests. It is a soluble monopotassium phosphate $\left(\mathrm{KH}_{2} \mathrm{PO}_{4}\right)$ which dissolves in water and contains $52 \% \mathrm{P}\left(\mathrm{P}_{2} \mathrm{O}_{5}\right)$ and $34 \% \mathrm{~K}\left(\mathrm{~K}_{2} \mathrm{O}\right)$. First, 300 $\mathrm{g}$ of MKP was dissolved in 100 liters of water for the tests. The fertilizer dilution in the reservoir was manually performed before the tests began (Borssoi et al., 2012).

The flow rate was collected for each test according to the methodology proposed by Keller \& Karmeli (1975). This

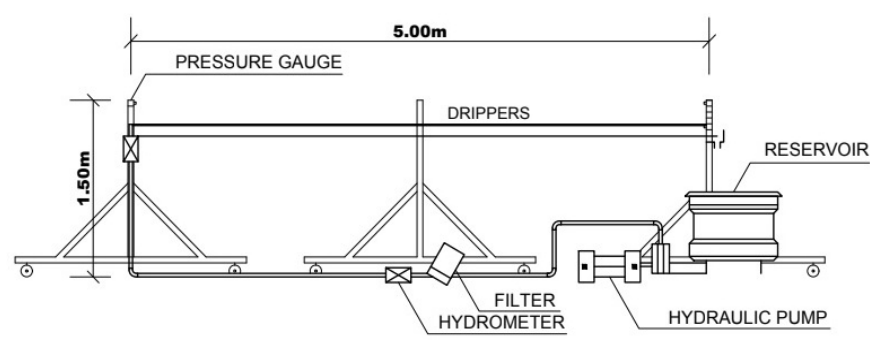

Figure 1. Illustration of the bench test used and its components. 
methodology consists of determining four emitters per lateral line, meaning the first dripper, the drippers located at 1/3 (70), and $2 / 3\left(13^{\circ}\right)$ of the lateral line length and the last dripper (20) in four lateral lines.

A total of 25 tests were carried out for each slope: level (0\%), upslope (2\%) and downslope (2\%) (ASABE, 1996). This number of samples was as recommended by Montgomery (2016) for quality control tests. A backwash using water was then carried out in the system after the end of the tests for the slopes.

The dripper flow was measured by the gravimetric method to obtain greater precision in the determination. The flow of the emitters was then determined by the volume collected in the drippers for $3 \mathrm{~min}$, as recommended by NBR 9261 (ABNT, 2006) and according to Equation 1.

$$
\mathrm{Q}=\frac{\mathrm{V}}{1000 \times \mathrm{t}} \times 60
$$

in which: $\mathrm{Q}$ - Flow rate, $\mathrm{L} \mathrm{h}^{-1} ; \mathrm{V}$ - Volume of the collected solution, $\mathrm{mL}$; $\mathrm{T}$ - Collection time, $\mathrm{min}$.

From the flow of the 16 drippers test (CUC), was calculated as shown in Equation 2:

$$
\mathrm{CUC}=\left(1-\frac{\sum_{\mathrm{i}=1}^{\mathrm{n}}\left|\mathrm{q}_{\mathrm{i}}-\overline{\mathrm{q}}\right|}{\mathrm{n} \overline{\mathrm{q}}}\right) \times 100
$$

in which: $q$ - arithmetic mean of the collected data, $L h^{-1} ; q_{i}$ flow rate in the dripper of order $\mathrm{i}, \mathrm{L} \mathrm{h}^{-1} ; \mathrm{n}$ - number of drippers evaluated in the irrigation system.

The CUC data were classified as described in Table 1.

Shewhart and EWMA control charts were used in the quality control process.

Calculating the upper control and lower limit (UCL and LCL) specifications is necessary to create Shewhart control charts, and these limits are obtained by Equations 3 and 4, respectively:

$$
\begin{aligned}
& \mathrm{UCL}=\overline{\overline{\mathrm{x}}}+3 \frac{\overline{\overline{\mathrm{AM}}}}{\mathrm{d}_{2}} \\
& \mathrm{LCL}=\overline{\overline{\mathrm{x}}}-3 \frac{\overline{\overline{\mathrm{AM}}}}{\mathrm{d}_{2}}
\end{aligned}
$$

Table 1. Classification of the Christiansen Uniformity Coefficient (CUC).

\begin{tabular}{cc}
\hline CUC (\%) & Classification \\
\hline$>90 \%$ & Excellent \\
$80-90 \%$ & Good \\
$70-80 \%$ & Regular \\
$60-70 \%$ & Bad \\
$<60 \%$ & Unaceptable \\
\hline
\end{tabular}

Source: Frizzone et al. (2012). in which: UCL - upper control limit; LCL - lower control limit; $x$ - data average; AM - average of data amplitudes; $d_{2}$ - constant equal to 1.128 for $n=2$, considering individual measures (Montgomery, 2016).

The EWMA control chart (Equation 5), is a weighted average of all past and current observations, and thus is insensitive to the normality hypothesis. It is ideal for use with observations and is defined as follows:

$$
\mathrm{Zi}=\lambda \mathrm{xi}+(1-\lambda) \mathrm{zi}-1
$$

in which: $0<\lambda \leq 1 ; \mathrm{Zi}=\mathrm{u} 0=\mathrm{x}$ (target value or mean value in $\mathrm{x}_{i}$ control).

The variance of the variable $\mathrm{Zi}$ is expressed as Equation 6.

$$
\sigma_{\mathrm{zi}}^{2}=\sigma^{2}\left(\frac{\lambda}{2-\lambda}\right)\left[1-(1-\lambda)^{2 \mathrm{i}}\right]
$$

in which: $\sigma$ - standard deviation of the data in relation to the mean; $\lambda$ - weight assigned to each sample; $i$ - order of sample used.

Montgomery (2016) reported that the UCL and the LCL of the EWMA control chart can be calculated by Equations 7 and 8 , respectively.

$$
\begin{aligned}
& \mathrm{UCL}=\overline{\mathrm{x}}+\mathrm{L} \sigma \sqrt{\frac{\lambda}{(2-\lambda)}\left[1-(1-\lambda)^{\mathrm{zi}}\right]} \\
& \mathrm{LCL}=\overline{\mathrm{x}}-\mathrm{L} \sigma \sqrt{\frac{\lambda}{(2-\lambda)}\left[1-(1-\lambda)^{\mathrm{zi}}\right]}
\end{aligned}
$$

in which: $x$ - average of the data; $\lambda$ - weight assigned to each sample, which varies from 0 to $1 ; \mathrm{L}$ - number of standard deviations to control the mean to be detected; $\mathrm{i}$ - order of sample used.

In this study, $\lambda=0.25$ is the weight constant of the sample, and the factor for the width of the limits is $L=2$.

The interpolation of the drip flow data was performed using the statistical model called distance inverse, described in Equation 9:

$$
z=\frac{\sum_{i=1}^{n} \frac{1}{d_{i}} z_{i}}{\sum_{i=1}^{n} \frac{1}{d_{i}}}
$$

in which: $\mathrm{z}$ - estimated value for point $\mathrm{z} ; \mathrm{n}$ - number of observations; $z_{i}$ - observed values.

The data were analyzed with analysis of variance (ANOVA) using the F-test at $5 \%$ probability. The comparison of means was performed using the Tukey test at $5 \%$ significance. All statistical and graphical analyses were performed using MINITAB 18 software. 


\section{Results and Discussion}

Water quality is an essential factor, as a problem such as the clogging of the emitters reduces the uniformity of the irrigation system. Water collected for the experiment were subjected to physicochemical analysis following the methodology of APHA (2012).

The physicochemical analysis of the water did not present any parameter which could influence the clogging of the emitters (Table 2). According to the findings by Capra \& Scicolone (1998), all physicochemical parameters present a low risk of clogging. However, the analyzed solution had a high copper content, with a value exceeding the tolerance of several crops for agricultural irrigation (Philippi Júnior, 2002).

There was a slight variation in flow in the lateral lines in the level system (Figure 2). The flow variation of the drippers occurs due to water energy loss by friction along the pipe and in the inserts of the drippers, a gain or loss of position energy, the quality of raw material and manufacturing processes, obstructions, and temperature effects of water on the flow regime and dripper geometry (Dias et al., 2005).

The highest flows regarding the upslope systems were found at the beginning of the system, and a drop in flow occurred until the end of the lateral lines (Figure 2). The flow is reduced due to the pressure drop along the stretch; however, uniformity continues (Alves et al., 2015).

The concentration of the highest flows at the end of the last lateral line in the downslope system is explained by the gradual increase in pressure which occurs until the end of the pipe (Marcuzzo \& Wendland, 2011). Klein et al. (2013) maintained that the greater downslope along the lateral line, the greater the flow.

Table 2. Physicochemical parameters of the solution with monopotassium phosphate (MKP).

\begin{tabular}{cc}
\hline Parameters & Value \\
\hline Total iron $\left(\mathrm{mg} \mathrm{L}^{-1}\right)$ & $0^{*}$ \\
Manganese $\left(\mathrm{mg} \mathrm{L}^{-1}\right)$ & $0^{*}$ \\
Potassium $\left(\mathrm{mg} \mathrm{L}^{-1}\right)$ & 1.03 \\
Sodium $\left(\mathrm{mg} \mathrm{L}^{-1}\right)$ & 6.5 \\
$\mathrm{pH}$ & $5.3^{*}$ \\
Nickel & 0 \\
Calcium $\left(\mathrm{mg} \mathrm{L}^{-1}\right)$ & $5.3^{*}$ \\
Magnesium $\left(\mathrm{mg} \mathrm{L}^{-1}\right)$ & $1.7^{*}$ \\
Barium $\left(\mathrm{mg} \mathrm{L}^{-1}\right)$ & 33.9 \\
Cadmium $\left(\mathrm{mg} \mathrm{L}^{-1}\right)$ & 0 \\
Chrome $\left(\mathrm{mg} \mathrm{L}^{-1}\right)$ & 0 \\
Copper $\left(\mathrm{mg} \mathrm{L}^{-1}\right)$ & 9.5 \\
Lead $\left(\mathrm{mg} \mathrm{L}^{-1}\right)$ & 0 \\
Zinc $\left(\mathrm{mg} \mathrm{L}^{-1}\right)$ & 0 \\
\hline
\end{tabular}

*Low risk of clogging.
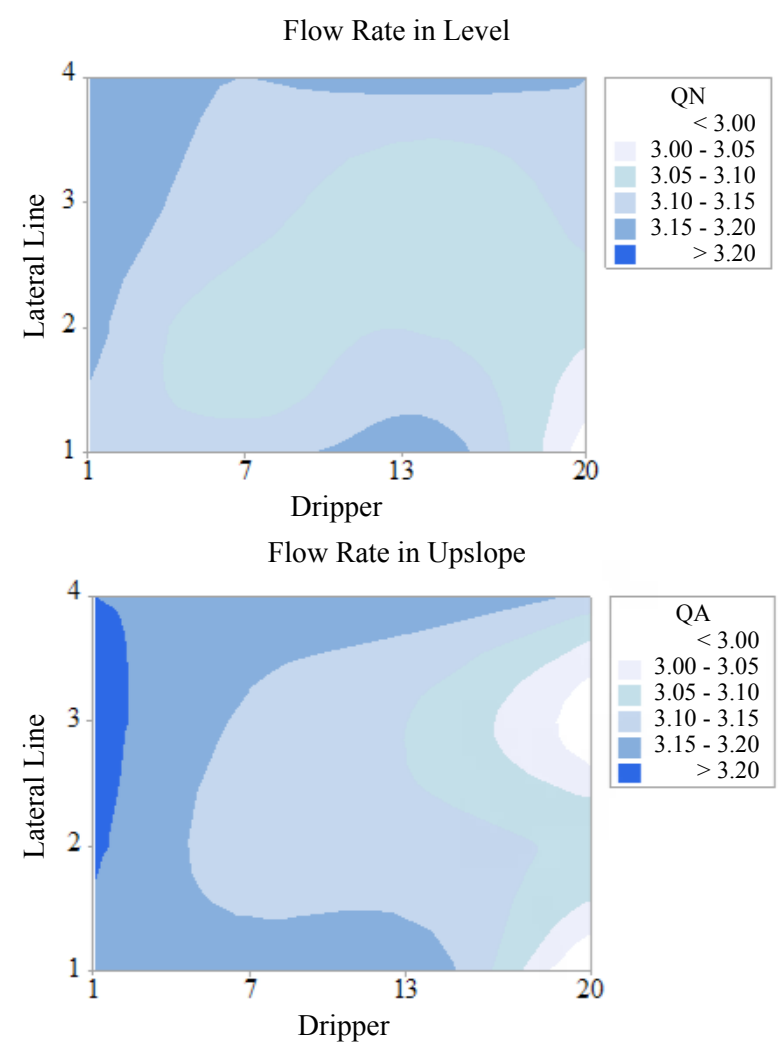

Flow Rate in Downslope
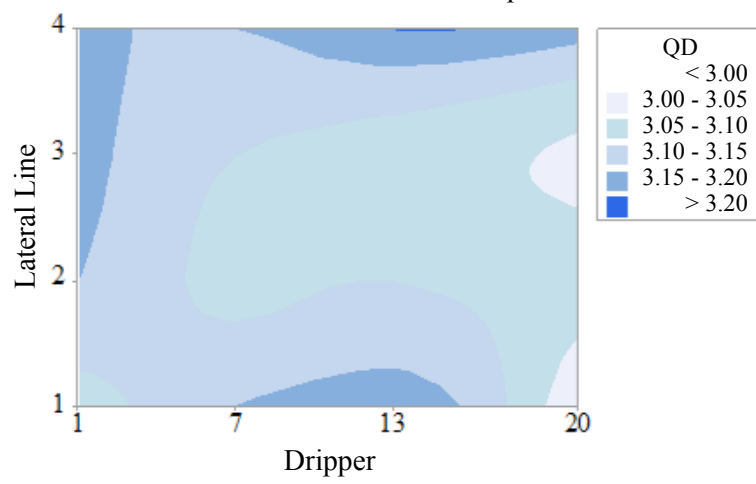

Figure 2. Spatial distribution of the irrigated area in level, upslope and downslope topographies.

The uniformity of the fertigation system with the use of MKP proved to be excellent for all slopes (>90\%), with the level system (98.51\%) and downslope system (98.44\%) being more uniform than the upslope system (98.02\%). Thebaldi et al. (2013) obtained a CUC of $94.59 \%$ to $96.99 \%$ when using purified monoammonium phosphate in drip irrigation (Table 3 ).

The level and downslope systems remained under statistical control, while the upslope system showed a point above the upper limit control, indicating that the uniformity was not within the performance established in the period (Figure 3).

Table 3. Descriptive statistics of the CUC of 25 trials of a drip fertigation system with MKP in level, upslope and downslope topographies.

\begin{tabular}{ccccccc}
\hline Slope & CUC (\%) & SD & CV (\%) & Variance & Minimum (\%) & Maximum (\%) \\
\hline Level & $98.51 \mathrm{a}$ & 0.173 & 0.18 & 0.0299 & 98.12 & 98.84 \\
Upslope & $98.02 \mathrm{~b}$ & 0.235 & 0.24 & 0.0551 & 97.66 & 98.64 \\
Downslope & $98.44 \mathrm{a}$ & 0.138 & 0.14 & 0.0192 & 98.16 & 98.73 \\
\hline
\end{tabular}

*Means followed by the same letter in the column do not differ, obtained by Tukey test at 5\% probability. SD: standard deviation; CV: coefficient of variation. 

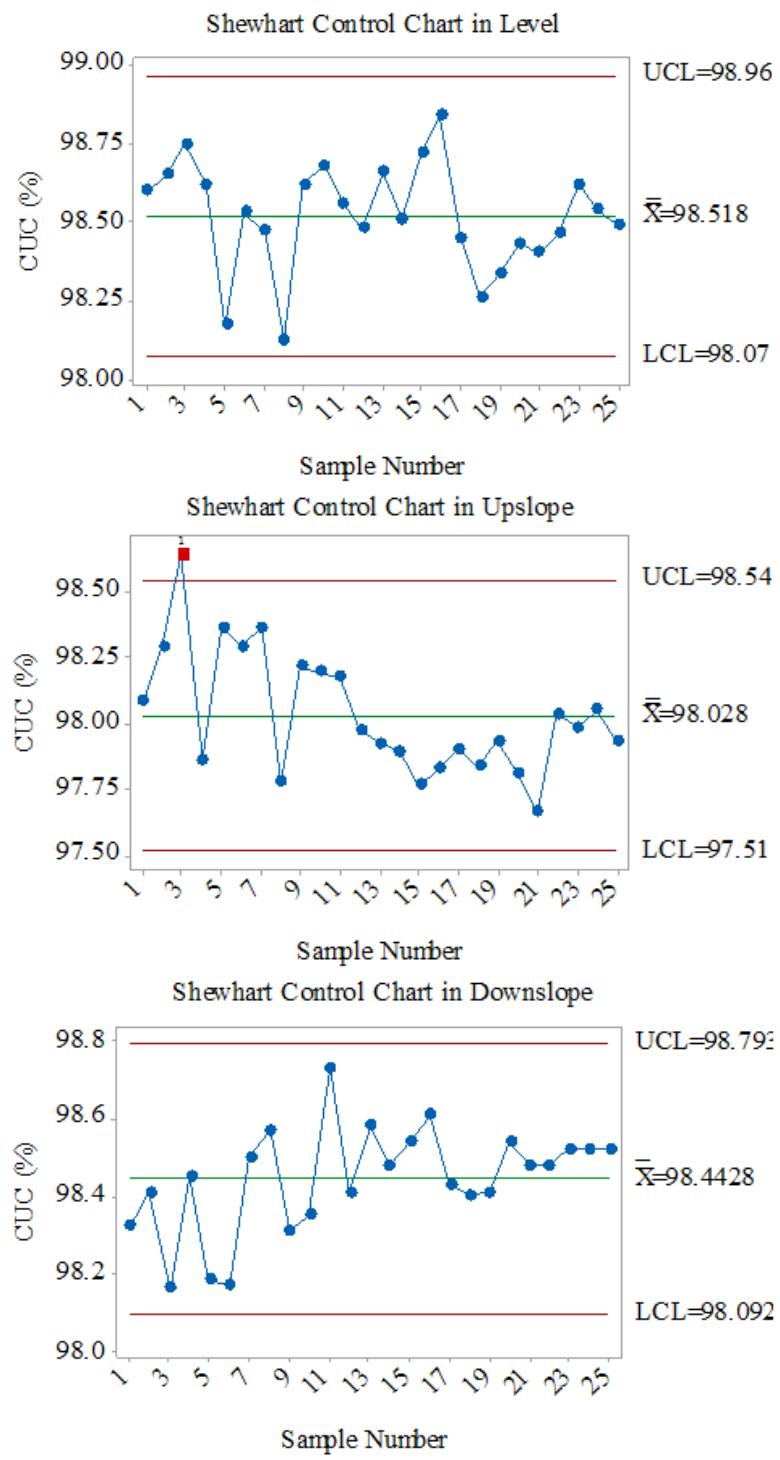

Figure 3. Shewhart control charts for CUC in level, upslope and downslope topographies.

Although the uniformity obtained excellent performance, it should be given special attention and investigated. Despite the excellent uniformity, variations in Shewhart control chart can indicate the appearance of clogging and flow-pressure variations in the irrigation system.

The EWMA control chart and Shewhart control chart demonstrated that the CUC of the system in the level topography remained under statistical control, and that of the upslope system was out of statistical control (Figures 3 and 4). However, there was a change in the downslope system whose CUC was out of statistical control. The Shewhart control chart is more robust, whereas the EWMA control chart indicates trends and deviations not shown by the Shewhart control chart (Lopes et al., 2020).

The EWMA control chart shows a downward trend in the uniformity of the upslope system during the process and an increase in uniformity for the downslope system (Figure 4). This observation is explained by the combined effect of pressure and gravity difference. Gravity helps downward
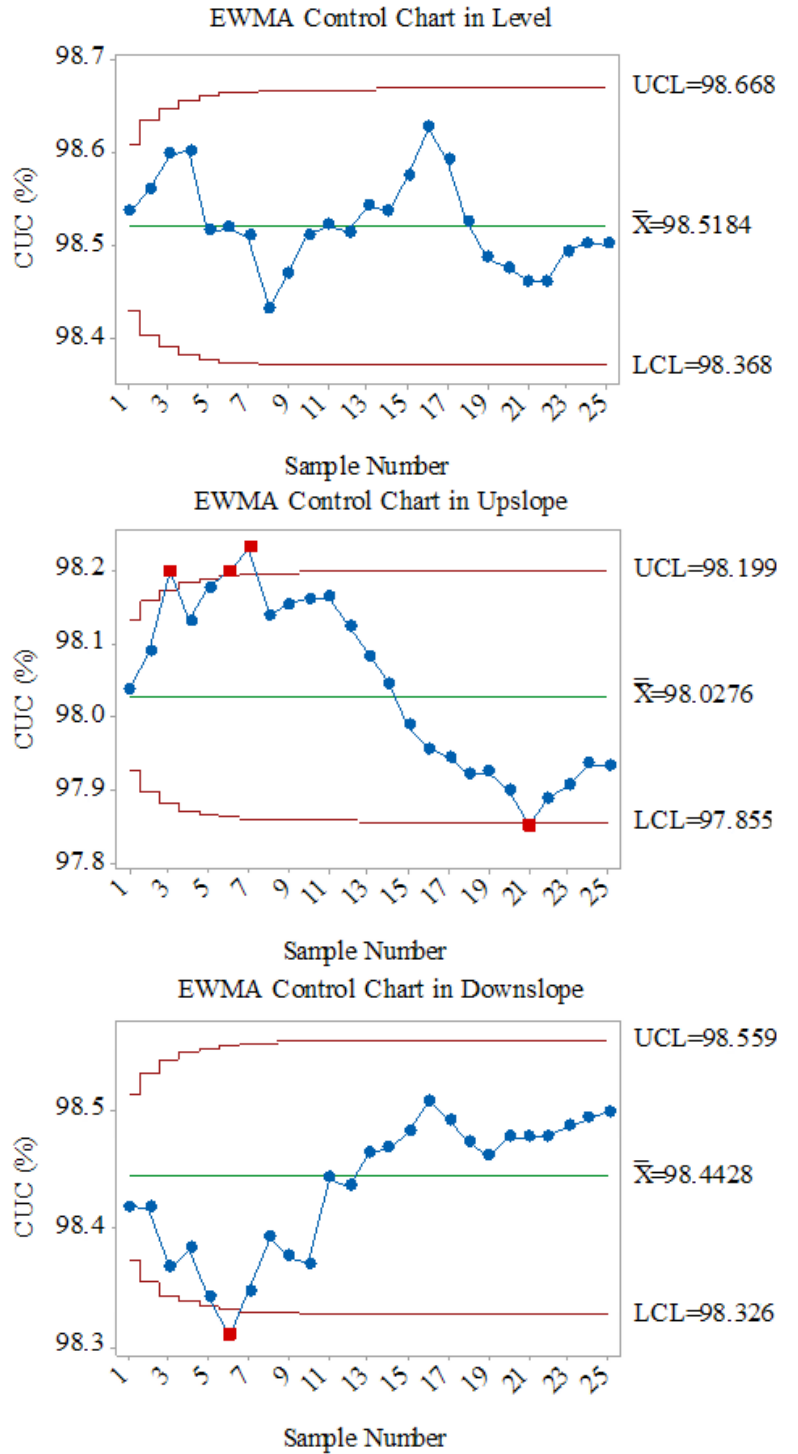

Figure 4. EWMA control charts for CUC in level, upslope and downslope topographies.

flow, but opposes upward flow (Çengel \& Simbala, 2015). The EWMA control chart is not only used to detect small variations (Ríaz et al., 2017), but also to check trends in the process (Shamsuzzaman et al., 2016).

\section{Conclusions}

The uniformity of the fertigation system with MKP proved to be excellent for all slopes (>90\%), with the level system (98.51\%) and downslope system (98.44\%) being more uniform than the upslope system (98.02\%).

There was a slight variation in flow in the lateral lines in the level system, while the highest flows in the upslope system were found at the beginning of the system, and the highest flows for downslope system were found at the end of the system.

Shewhart control charts proved to be more robust than EWMA control charts, as they indicated fewer points outside the statistical control limits. 
Through the control charts, trends and problems that occurred during the fertigation process, could be identified, and thus indicated for monitoring.

\section{Compliance with Ethical Standards}

Funding: Not applicable.

Conflict of interest: Authors declare any possible conflict of interest (professional or financial) that may influence the article.

Author contribution: Conceptualization: ARL, MAVB; Data curation: ARL, RTCP, FAP, LDC; Formal analysis: ARL; Funding acquisition: $A R L, M A V B, B M G, R T C P$; Investigation: ARL, RTCP, FAP, LDC; Methodology: ARL, MAVB, FAP, LDC; Project administration: ARL, MAVB; Resources: ARL, MAVB, RTCP, LDC; Supervision: MAVB; Validation: ARL, BMG, RTCP; Visualization: ARL, MAVB, RTCP; Writing - original draft: ARL; Writing - review \& editing: ARL, MAVB, BMG.

\section{Literature Cited}

Alves, E.S.; Araújo, L.M.; Alves, J.S.D.; Santos, J.E.O.S.; Zimback, C.R.L. Geoestatística aplicada à uniformidade de aplicação de água em sistema de irrigação por gotejamento usado e novo. Revista Brasileira de Agricultura Irrigada, v.9, n.3, p.127-135, 2015. https://doi.org/10.7127/rbai.v9n300298.

American Public Health Association - APHA. Standard methods for the examination of water and wastewater. Washington: APHA, 2012. 1496 p.

American Society of Agricultural and Biological Enginners - ASABE. Field evaluation of micro-irrigation systems. St. Joseph: ASABE, 1996. p. 792-797.

Associação Brasileira de Normas Técnicas - ABNT. Equipamentos de irrigação agrícola - Emissores e tubos emissores - Especificações e métodos de ensaio. ABNT NBR ISSO 9261. São Paulo: ABNT, 2006. 17p.

Borssoi, A.L.; Vilas Boas, M.A.; Reisdörfer, M.; Hernandéz, R.H.; Follador, F. Water application uniformity and fertigation in a dripping irrigation set. Engenharia Agrícola, v.32, n.4, p.718-726, 2012. https://doi.org/10.1590/S0100-69162012000400011.

Capra, A.; Scicolone, B. Water quality and distribution uniformity in drip/trickle irrigation systems. Journal of Agricultural Engineering Research, v.70, n.4, p.355-365, 1998. https://doi. org/10.1006/jaer.1998.0287.

Çengel, Y.A.; Cimbala, J.M. Mecânica dos fluidos: fundamentos e aplicações. Porto Alegre: AMGH, 2005. 990 p.

Chapagain, B.P.; Wiesman, Z. Effect of nutri-vant-peak foliar spray on plant development, yield and fruit quality in greenhouse tomatoes. Scientia Horticulture, v.102, p.177-188, 2004. https://doi.org/10.1016/j.scienta.2003.12.010.

Chinchilla, S.R.A.; Silva, E.F.F.; Almeida, C.D.G.C.; Silva, A.O.; Santos, P.R. Statistical process control in the assessment of drip irrigation using wastewater. Engenharia Agrícola, v.38, n.1, p. 47-54, 2018. https://doi.org/10.1590/1809-4430-eng.agric. v38n1p47-54/2018.
Coelho, E.F.; Or, D.; Sousa, V.F. Aspectos básicos em fertirrigação. In: Sousa, V.F.; Marquelli, W.A.; Coelho, E.F.; Pinto, J.M.; Coelho Filho, M.A. (Eds.). Irrigação e fertirrigação em fruteiras e hortaliças. Brasília: Embrapa, 2011. p. 235-251.

Conceição, K.Z.; Vilas Boas, M.A.; Sampaio, S.C.; Remor, M.B.; Bonaparte, D.I. Statistical control of the process applied to the monitoring of the water quality index. Engenharia Agrícola, v.38, n.6, p.951-960, 2018. https://doi.org/10.1590/1809 4430-eng.agric.v38n6p951-960/2018.

Cunha, F.F.; Silva, T.R.; Muchalak, S.M.; Magalhães, F.F.; Silva, S.Q. Gotejadores e dispositivos final de linha operando com águas contendo material orgânico. Engenharia na Agricultura, v.25, n.2, p.173-181, 2017. https://doi.org/10.13083/reveng. v25i2.764.

Cunha, F.N.; Teixeira, M.B.; Rodrigues, C.R.; Moraes, G.S.; Silva, I.O.F.; Alves, D.K.M. Uniformidade de irrigação por gotejamento sob fertirrigação com fontes de nitrogênio. Revista Brasileira de Agricultura Irrigada, v.12, n.7, p.3118-3128, 2018. https://doi. org/10.7127/rbai.v12n7001006.

Dias, N.S.; Medeiros, J.F.; Teixeira, M.B. Avaliação de diferentes modelos, vazões e espaçamentos de gotejadores na irrigação do meloeiro. Irriga, v.10, n.3, p.263-271, 2005. https://doi. org/10.15809/irriga.2005v10n3p263-271.

Fan, M.; Bie, Z.L.; Krumbein, A.; Schwarz, D. Salinity stress in tomatoes can be alleviated by potassium depending on rootstock and $K$ concentration employed. Scientia Horticulturae, v. 130, n. 3, p. 615-623, 2011. https://doi.org/10.1016/j.scienta.2011.08.018.

Foratto, L.C.; Zanini, J.R.; Natale, W. Teor de fósforo e pH no bulbo molhado, com diferentes frequências de fertirrigação, utilizando ácido fosfórico. Engenharia Agrícola, v.27, n.2, p. 436-444, 2007. https://doi.org/10.1590/S0100-69162007000300012.

Frizzone, J.A.; Freitas, P.S.L.; Rezende, R.; Faria, M.A. Microirrigação: Gotejamento e microaspersão. Maringá: EDUEM, 2012. 356 p.

Keller, J.; Karmeli, D. Trickle irrigation design parameters. Transactions of the ASAE, v.17, n.4, p. 678-684, 1975. https://doi. org/10.13031/2013.36936.

Klein, M.; Szekut, F.; Suszek, F.; Reis, C.; Aymoré, C.; Guerra, J.; Vilas Boas, M.A. Uniformidade de irrigação e fertigação em um sistema de irrigação familiar por gotejamento sob diferentes cargas hidráulicas. Engenharia Ambiental, v.10, n.3, p.56-69, 2013.

Lopes, A.R.; Vilas Boas, M.A.; Pazuch, F.A.; Dalla Corte, L.; Ostroski, D.A.; Remor, M.B.; Mohr, F.B.M.; Dotto, M.; Zanella, A.P.; Carvalho, A.F.G.; Freddo, A.R.; Bertoldo, I.C.; Pirola, K.; Giarola, C.M. Statistical quality control in uniformity of drip irrigation with different slopes. Journal of Agricultural Science, v. 11, n. 16, p. 195-205, 2019. https://doi.org/10.5539/jas.v11n16p195.

Lopes, A.R.; Vilas Boas, M.A.; Pazuch, F.A.; Ostroski, D.A.; Schmatz, M.J. Control charts for monitoring drip irrigation with different hydraulic heads. Revista Ambiente \& Água, v. 15, n. 4, p. 1-10, 2020. https://doi.org/10.1590/S0104-530X2013000200003.

Marcuzzo F.F.N.; Wendland, E. Distribuição de pressão em rede de irrigação localizada otimizada por algoritmos genéticos. Engenharia Agrícola, v.31, n.3, p.497-505, 2011. https://doi. org/10.1590/S0100-69162011000300010. 
Montgomery, D. C. Introdução ao controle estatístico da qualidade. Rio de Janeiro: LTC, 2016. 549 p.

Orssatto, F.; Vilas Boas, M.A.; Eyng, E. Gráfico de controle da média móvel exponencialmente ponderada: aplicação na operação e monitoramento de uma estação de tratamento de esgoto. Engenharia Sanitária e Ambiental, v.20, n.4, p.543-550, 2015. https://doi.org./10.1590/S141341522015020040093742.

Philippi Júnior, A. Reúso de água. São Paulo: Editora Manole, 2002. $550 \mathrm{p}$.

Ríaz, M.; Mahmood, T.; Abbasi, S.A.; Abbas, N.; Ahmad, S. Linear profile monitoring using EWMA structure under ranked set schmes. International Journal of Advanced Manufacturing Technology, v.91, p.2751-2775, 2017. https://doi.org/ 10.1007/ s00170-016-9608-y.

Sajyan, T.K.; Shaban, N.; Rizkallah, J.; Sassine, Y.N. Effects of monopotassiumphosphate, nano-calcium fertilizer, acetyl salicylic acid and glycinebetaine application on growth and production of tomato (Solanum lycoppersicum) crop under salt stress. Agronomy Research, v. 16, n. 3, p. 872-883, 2018. https://doi.org/10.15159/ar.18.079.
Shamsuzzaman, M.; Khoo, M.B.C.; Haridy, S.; Alsyouf, I. An optimization design of the combined Shewhart-EWMA control chart. International Journal of Advanced Manufacturing Technology, v.86, p.1627-1637, 2016. https://doi.org/10.1007/s00170-015-8307-4.

Siqueira, M.M.K.; Vilas Boas, M.A.; Siqueira, J.A.C.; Tokura, L.K. Techniques for quality control in football field located in agricultural area. Journal of Agricultural Science, v.10, n.9, p.430442, 2018. https://doi.org/10.5539/jas.v10n9p430.

Thebaldi, M.S.; Rocha, M.S.; Sandri, D.; Felisberto, A.B.; Avelino Neto, S. Diferentes tipos de água e seu efeito na uniformidade de gotejadores na cultura de tomate. Irriga, v.18, p.212-222, 2013. https://doi.org/10.15809/irriga.2013v18n2p212.

Vieira, C.R.; Weber, O.L.; Scaramuzza, J.F. Saturação por bases e doses de $P$ no crescimento de nutrição de mudas de cerejeira (Amburana Acreana Ducke). Nativa, v.3, n.1, p.1-9, 2015. https:// doi.org/10.14583/2318-7670.v03n01a01.

Zanini, J.R.; Barreto, A.K.G.; Foratto, L.C.; Natale, W. Distribuição de fósforo no bulbo molhado aplicado via fertrrigação por gotejamento com ácido fosfórico. Engenharia Agrícola, v.27, n.1, p. 180-193, 2007. https://doi.org/10.1590/S0100-69162007000100012. 